\title{
Ashes from Sewage Sludge and Bottom Sediments as a Source of Bioavailable Phosphorus
}

\author{
Tomasz Ciesielczuk ${ }^{1 *}$, Czesława Rosik Dulewska², Joanna Poluszyńska ${ }^{3}$, \\ Ewelina Ślęzak³ Katarzyna Łuczak \\ 1 Department of Land Protection, Opole University, ul. Oleska 22, 45-052 Opole, Poland \\ 2 Institute of Environmental Engineering of the Polish Academy of Sciences, ul. Skłodowskiej-Curie 4, \\ 41-819 Zabrze, Poland \\ 3 Institute of Ceramics and Building Materials, ul. Oswiecimska 21, 45-641 Opole, Poland \\ *Corresponding author's e-mail: tciesielczuk@uni.opole.pl
}

\begin{abstract}
Phosphorus is an element necessary for the growth of plants. As phosphate rock gets depleted, it becomes an increasingly scarce resource. Therefore, it seems necessary to implement simple methods of cheap and effective phosphorus recovery from waste. The ashes of municipal sewage sludge and bottom sediments constitute particularly valuable sources of phosphorus. However, these materials usually carry significant amounts of pollutants, including heavy metals. Optimization of ash phosphorus sequential extraction methods from a thermal conversion of sewage sludge and bottom sediments allows to select an effective and simple technology of phosphorus recovery, while maintaining low heavy metal pollution, which is one of the main restrictions in use of ashes. Determination of an amount of bioavailable phosphorus is therefore a basis for estimation of the possibility of using it from waste. Extraction using the Golterman method or shaking out with calcium lactate or Trougs reagent indicates that the ashes from sewage sludge and bottom sediments are rich sources of bioavailable phosphorus, which could find use under field conditions as a viable alternative to fertilizers containing fossil phosphorus.
\end{abstract}

Keywords: phosphorus, bioavailability, ash, sewage sludge, bottom sediments, extraction

\section{INTRODUCTION}

Phosphorus is an essential element in agriculture, and the yield depends, i.a. on the occurrence of its bioavailable forms. In the agricultural practice, it is widely used in the form of mineral and organic fertilizers.

Apart from manure, bird guano was considered in the last century as a source of phosphorus. Acquiring this bird manure (coming mainly from seabirds) which is extremely rich in nutrients, allowed for its introduction to the European market despite a high price (Szpak et al. 2012). After popularization of mineral fertilizers production, the exploitation of guano has become uneconomic. However, this necessitated phosphate mining in North America, Ukraine, Russia and West Africa.
About $90 \%$ of these minerals are converted into phosphate fertilizers, the use of which will grow at a rate of 1.5-3.6\% per annum (Szaja 2013). However, taking into consideration the material price instability and its dwindling resources, new, alternative sources of this precious element are sought (van Vuuren et al. 2010).

The phosphorus-rich waste is also generated in large quantities of municipal sewage sludge, the amount of which in Poland in 2016 equaled 568.3 thousand $\mathrm{Mg}$ d.m., with the average phosphorus content of about $3 \%$, which gives over 17 thousand $\mathrm{Mg}$ of phosphorus, annually (Bień 2012, Statistical Yearbook of Environmental Protection 2017).

The use of municipal sewage sludge is most often limited by a significant content of heavy 
metals, persistent organic pollutants and sometimes by the presence of living intestinal parasitic eggs (Poluszyńska and Ślęzak 2015). Actions were also taken to produce agricultural fertilizer, stabilizing sediments with ash from brown coal combustion. However, the problem of high content of heavy metals and polycyclic aromatic hydrocarbons (PAHs) that can migrate from the soil into the food chain, may limit its use in agriculture (Rosik-Dulewska et al. 2008, Rosik-Dulewska et al. 2016, Poluszyńska 2013).

The current trends of using solar energy for sludge drying create opportunities for using the dry sludge for thermal transformation, i.e. one with energy recovery (Bień 2012). The ash generated as a result of combustion of sewage sludge consists mainly of $\mathrm{Si}, \mathrm{Fe}, \mathrm{Al}, \mathrm{Ca}$ and $\mathrm{P}$, including significant amounts of heavy metals, 9 to 13 times higher in relation to their content in the sediments from which the ash was created. It excludes their use in agriculture (Guedes et al. 2016). However, a significant amount of phosphorus, which may reach even $11-13.4 \%$, predestines it for recovery with prior heavy metal elimination (Donatello et al 2010, Guedes et al. 2014). The importance of the problem is emphasized by the European SUSAN project aimed at optimizing the methods of nutrients recovery from sewage sludge, while at the same time minimizing the risk of heavy metals or persistent organic pollutants (Adam et al. 2009). The bottom sediments of water reservoirs and rivers are also of similar importance. Although they release significant amounts of heavy metals when used as fertilizers, their drying and combustion opens new possibilities for phosphorus recovery, especially in its bioavailable forms (Strzebońska et al. 2015).

\section{MATERIALS AND METHODS}

The research material involved the ashes from the thermal transformation of municipal sewage sludge and bottom sediments rich in organic matter. The sewage sludge came from municipal wastewater treatment plants without (OL) and with increased nutrient removal (OP) as well as the ashes from industrial incineration plant (OS). The bottom sediments (OD) came from the dam part of the "Jezioro Turawskie Duże" reservoir located on the Mała Panew river in the Opolskie voivodeship (Poland). OP, OL and OD samples were incinerated at $600^{\circ} \mathrm{C}$ for 3 hours, while the
OS sample was created as a result of burning sewage sludge at $850^{\circ} \mathrm{C}$ in the municipal sludge incineration plant in Nowiny (Poland).

The following parameters were designated in the tested materials: $\mathrm{pH}$, proper electrolytic conductivity by potentiometric methods and the content of organic matter by weight. The content of calcium, sodium and potassium were determined using the FES method and the BWB-XP apparatus.

In order to assess the quantitative share of bioavailable phosphorus forms in the studied ashes, six methods proposed in the literature were used. The first one includes distilled water extraction $(1: 20, \mathrm{w} / \mathrm{v})$ in $22 \mathrm{~h}$. After centrifugation, the supernatant was infused with $0.2 \mathrm{~cm}^{3} 0.12 \mathrm{M}$ $\mathrm{MgCl}_{2}$ and centrifuged again (Boen et al., 2013). The second method is extraction with $2 \%$ citric acid (CA) (Krupa-Żuczek et al. 2012). The third method involves extraction of phosphorus with the Trougs's reagent (TS) $\left(0.002 \mathrm{~N} \mathrm{H}_{2} \mathrm{SO}_{4}+0.3 \%\right.$ $\left.\left(\mathrm{NH}_{4}\right)_{2} \mathrm{SO}_{4}\right)$, which was buffered to $\mathrm{pH} 3.00$. The mass-volume ratio ash:extractant was 1:200 at the shaking time of $30 \mathrm{~min}$. The obtained extract was marked colorimetrically using the molybdate blue method (Chiu et al. 2006). The fourth method is the Egner-Rhiem (E-R) procedure using $0.04 \mathrm{M}$ calcium lactate with lactic acid after buffering to pH 3.55 (Wójcik et al., 2014). In the preliminary tests, the control sample was the extractant itself. The fifth method was based on the extraction with sodium bicarbonate buffered to pH 8.5 according to Olsen (OLS), which is recommended for alkaline soils. The mass-volume ratio ash:extractant was 1:20 at the shaking time: $30 \mathrm{~min}$. (Olsen et al. 1954).

For comparison, the Golterman methodology, developed for the bottom sediments of water reservoirs, was applied. This method consists of shaking the sample with extrinsic agents of varied strength (Table 1). Total phosphorus content (PTOT) in the tested samples was determined with ICP-MS after microwave digestion in aqua regia.

\section{RESULTS AND DISCUSSION}

The tested ashes from sewage sludge incineration were alkaline and neutral in the case of ash from bottom sediments (Table 2), which is characteristic for this type of waste. The electrolytic conductivity was high and in the case of application as fertilizer it could pose a threat to plant seedlings (Mazur et al. 2013). 
Table 1. Procedure for extracting tested ashes according to Golterman (Golterman 1996)

\begin{tabular}{|c|c|l|}
\hline Stage and extraction time & Extractant & \multicolumn{1}{c|}{ Fraction } \\
\hline G I $4 \mathrm{~h}$ & $0.05 \mathrm{M} \mathrm{Ca}-E D T A$ & $\begin{array}{l}\text { Phosphorus bound with ferric, aluminium and manganese } \\
\text { oxides and hydroxyoxides }\end{array}$ \\
\hline G II $18 \mathrm{~h}$ & $0.1 \mathrm{M} \mathrm{Na}_{2}$-EDTA & Phosphorus bound with carbonates \\
\hline G III $2 \mathrm{~h}$ & $0.5 \mathrm{M} \mathrm{H}_{2} \mathrm{SO}_{4}$ & Phosphorus from soluble compounds with organic matter \\
\hline G IV $2 \mathrm{~h}$ & $2 \mathrm{M} \mathrm{NaOH}$ & $\begin{array}{l}\text { Phosphorus bound with aluminosilicates and in organic } \\
\text { matter resist on sulphuric acid digestion in stage G III }\end{array}$ \\
\hline
\end{tabular}

The content of nutrients $\left(\mathrm{CaO}, \mathrm{MgO}, \mathrm{K}_{2} \mathrm{O}\right)$ was high and characteristic for the ashes from bottom sediments and sewage sludge incineration (Arnout and Nagels 2016, Donatello et al. 2010), which proves their high value, not only as a fertilizer, but also as a deacidifying agent for soil.

Sewage sludge and bottom sediments contain a significant amount of phosphorus-rich organic matter. If the content of heavy metals meets the legal requirements, these sediments can be used naturally (also as fertilizers) to improve the soil structure, increase its water absorption and as suppliers of many valuable elements for plants, including micronutrients (Rosik-Dulewska et al. 2016). Nevertheless, in many cases the sewage sludge, after initial drying, is subject to incineration in specialized incinerators. In some countries (Holland, Switzerland), the entire amount of generated sediments is burned (Herzel et al. 2016).

However, the ash obtained from sewage sludge may contain high concentrations of metals, especially zinc, copper, chromium and lead. Making the law more flexible and rapidly passing new legal acts would allow to improve the phosphorus recovery technology (energy and material consumption) on the one hand, and to establish economic incentives (taxes, subsidies) for the companies investing in phosphorus recovery installations on the other (Hukari et al. 2016). After incineration of sewage sludge or bottom sedi- ments, while there is no longer any valuable organic matter, the amount of phosphorus increases to even a dozen or so percent, making this material a valuable source of this element, equally to phosphate fertilizers, and the attempts to wash out phosphorus from ash are carried out by strongly acidic extractants (Atineza-Martinez et al. 2014, Ebbers et al. 2015).

In the ashes from sewage sludge, the bioavailable phosphorus is present in relatively large quantities and constitutes on average over $30 \%$ of the total phosphorus, which creates considerable opportunities for using this material as an agricultural fertilizer (Kruger and Adam 2015). Although the process of sludge incineration demands significant investment costs, it eliminates the organic toxic compounds found in sediments, and at the same time, by mineralization of organic matter, it "enriches" the obtained material with phosphorus. Finally, in the ashes from sewage sludge, the total phosphorus can exceed $16.0 \%$ (Guedes et al 2016). In the municipal sewage sludge research, the total phosphorus content was recorded in the range 2.97-6.64\% (Poluszyńska and Ślęzak 2015), while in the sludge ash examined here, these values range between 13.8 and $18.4 \%$. Only in bottom sediments, the phosphorus content was lower $(4.6 \%)$ and comparable with the data obtained by the other authors (Bezak-Mazur and

Table. 2. General characteristics of tested ashes OP, OL, OS and OD $(n=3)$

\begin{tabular}{|c|c|c|c|c|}
\hline Description & OP & $\mathrm{OL}$ & OS & OD \\
\hline $\mathrm{pH}_{\mathrm{H} 2 \mathrm{O}}[-]$ & $7.78-7.83$ & $8.48-8.52$ & $9.78-9.85$ & $6.90-7.01$ \\
\hline $\mathrm{EC}[\mathrm{mS} / \mathrm{cm}]$ & $3.77(0.11)$ & $2.98(0.08)$ & $2.26(0.04)$ & $2.33(0.13)$ \\
\hline TC [\%] & $0.84(0.16)$ & $1.13(0.15)$ & $0.17(0.08)$ & $0.91(0.01)$ \\
\hline $\begin{array}{c}\mathrm{CaO} \\
{[\mathrm{g} / \mathrm{kg} \text { d.m.] }}\end{array}$ & 109.3 & 16.68 & 20.59 & 1.973 \\
\hline $\begin{array}{c}\mathrm{MgO} \\
\text { [g/kg d.w.] }\end{array}$ & 12.2 & 14.8 & 18.6 & 2.49 \\
\hline $\begin{array}{c}\mathrm{Na}_{2} \mathrm{O} \\
{[\mathrm{g} / \mathrm{kg} \text { d.w.] }}\end{array}$ & 3.419 & 6.280 & 3.665 & 0.355 \\
\hline $\begin{array}{c}\mathrm{K}_{2} \mathrm{O} \\
{[\mathrm{g} / \mathrm{kg} \text { d.w.] }}\end{array}$ & 5.364 & 8.247 & 10.85 & 2.301 \\
\hline
\end{tabular}

Note: Standard deviation (SD) value in brackets. 
Stoińska 2013, Havukainen and others 2016). Many efficient methods of phosphorus recovery have been developed thus far, but they do not give the right perspective of bioavailable forms content, because of the use of aggressive extractants and high temperature, which also makes the forms practically unavailable to plants (Petzet et al. 2012, Shiba and Ntuli 2016, Weigand et al. 2013, Wzorek 2008).

\section{PRELIMINARY TESTS}

In the conducted tests, there was a strong correlation between the amount of "bioavailable" phosphorus and the $\mathrm{pH}$ of an extraction solution. While using the TS method to extract the OP samples, acidification of the solution with $\mathrm{H}_{2} \mathrm{SO}_{4}$ with $\mathrm{pH} 3.00$ (recommended in the method) to 0.88 , increased the amount of marked phosphorus by $184 \%$. The correlation ratio of the $\mathrm{pH}$ value and the amount of eluted phosphorus was 0.997 . The method, used to extract highly alkaline biomass ash (after adding the extractant to the sample, a reaction of 7-8 is obtained instead of the expected 3-4), after acidification from $\mathrm{pH} 7.31$ to 0.55 , the amount of phosphorus obtained increased by $2731 \%$, and the correlation coefficient in this case was 0.999 . This confirms the effect of $\mathrm{H}_{2} \mathrm{SO}_{4}$ as an extractant capable of decomposing even hardly soluble phosphorus-containing minerals (Tujaka et al. 2006). The need to correct the reaction by adding a strong extractant was confirmed by other authors (Wzorek et al. 2006). Additional acidification facilitates the dissolution of calcium-bound phosphates, as well as partially ironbound, which, because of a significant amount of such forms in the ash, can significantly affect the recovery rate (Bednarek and Reszka 2007).

In our own research, we have also tested the influence pertaining to the time of contact between the extractant and the ash sample, on changing the $\mathrm{pH}$ value of the extraction solution. For comparison, the data obtained for oak biomass ashes burned at $600^{\circ} \mathrm{C}$ (Fig. 1) was also introduced. The obtained results indicate a small increase in the $\mathrm{pH}$ value in

The case of OP and OL samples as well as $\mathrm{pH}$ change by 2 degrees in the case of biomass ash (BM test). The reaction of the extractant is of fundamental importance for the amount of phosphorus leached from a given material; therefore, special attention should be paid to the possibility of obtaining low results, especially in the case of strongly alkaline substances (Golterman 1996).

\section{COMPARISON OF EXTRACTION METHODS}

The ashes from the analyzed sewage sludge contained between $13.8 \%$ and $18.4 \% \mathrm{P}_{2} \mathrm{O}_{5}$, which is also confirmed by the results of the research carried out by other authors, who assessed it as very rich in this element (Havukainen et al. 2016). Only the ash from bottom sediments was characterized by a much lower amount of phosphorus, i.e. $0.46 \% \mathrm{P}_{2} \mathrm{O}_{5}$. It is still a valuable amount as far as the usage as a fertilizer is concerned.

On the basis of the preliminary tests and available literature, it was assumed that the amount of bioavailable phosphorus obtained in the experiments with OP, OL, OS and OD samples shall depend on the type of the extractant used. The phos-

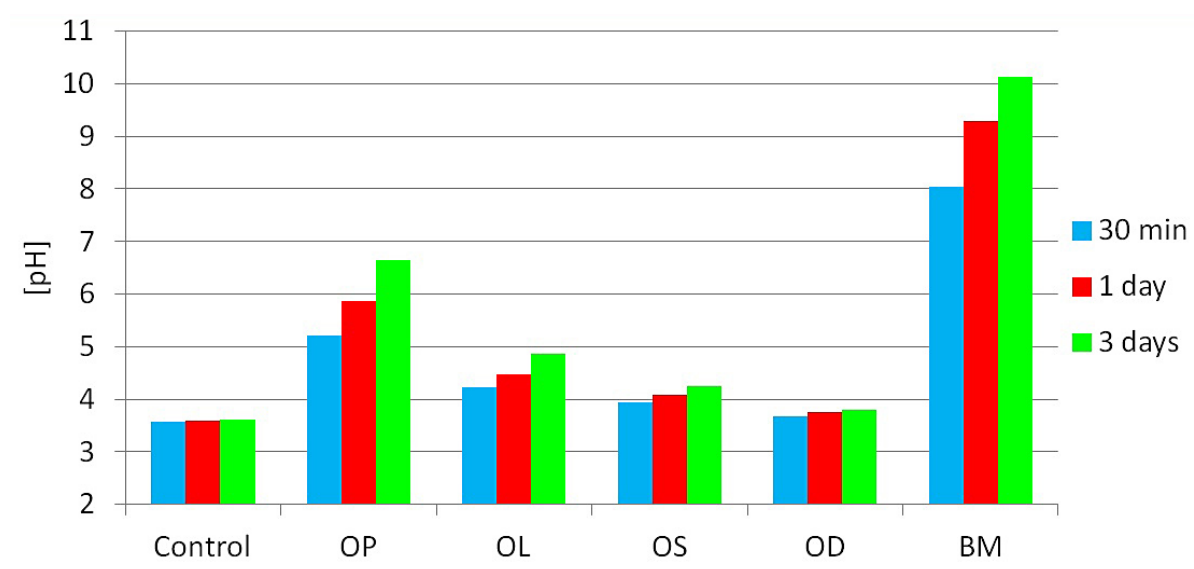

Figure 1. Changes in the $\mathrm{pH}$ value in the process of bioavailable phosphorus extraction using the E-R method and $0.04 \mathrm{M}$ calcium lactate as control 
phates contained in the tested samples (despite the long contact time), dissolved in water only to a small extent - WE method (Table 1). The phosphorus levels eluted in this way were very low and only slightly exceeded $0.04 \%$ of total phosphorus. The highest efficiency of this method (WE) was obtained for the OD ash. Such low amounts washed out with water are not confirmed by the results of Bednarek and Reszka, obtained in a pot experiment with limed soil fertilized with phosphorus. However, it should be noted that in the experiment, the ashes from sediments were not used (Bednarek and Reszka 2007). The citric acid method was much more effective, since it obtained between 4.5 and $6.4 \%$ of the total amount of phosphorus marked in the samples.

Using the Trougs and Egner-Rhiem methods, i.e. using extraction liquids with a similar $\mathrm{pH}$, the results were obtained with a predominance (up to 2x) in favor of the E-R method (Table 3). Their efficiency was at the level of $1.2-3.3 \%$ of the total phosphorus content in the case of sewage sludge ashes. Higher amounts exceeding 6 and $12 \%$ of total phosphorus were recorded only in dermal sediment samples (OD samples) for TS and E-R respectively. Due to the fact that acidified calcium lactate $\mathrm{HCl}$ elutes mainly phosphorus compounded with calcium and iron, the presence of these compounds will have a significant impact on the obtained effects (Bednarek and Reszka 2007). Considering the influence of the extractant reaction on the amount of leached phosphorus (part: Preliminary tests), it should be concluded that the values obtained by $\mathrm{W}, \mathrm{CA}, \mathrm{TS}$ and $\mathrm{ER}$, due to the high ash reaction, are understated and the actual amount of bioavailable forms is higher.
Olsen extraction of phosphorus used for acidic and neutral soils may give erroneous results, but in the case of alkaline soils, it simulates the conditions present during the water-soil contact very well. Therefore, in the ash from sediments characterized by relatively high $\mathrm{pH}$, this method should determine the actual amount of phosphorus available for plants. The amount of phosphorus determined according to the Olsen's methodology in the eluates from OP, OL and OS samples is 2-8 times lower than in the E-R method, which is justified by the higher $\mathrm{pH}$ of the extractant, and thus the reduced solubility of phosphorus compounds. The best results were noted for the OD samples which obtained almost $4.5 \%$ of the total phosphorus content. The fly ashes from coal combustion are characterized by a reaction above 10 and containing $1.17 \mathrm{~g} \mathrm{P}_{2} \mathrm{O}_{5} / \mathrm{kg} \mathrm{d.m}$. showed a similar (3.37\%) amount of bioavailable phosphorus as in the OD samples. Moreover, it has been shown that a significant content of calcium reduces the amount of bioavailable phosphorus up to 10 times (Seshardi et al. 2013).

Using the Golterman sequential extraction method, the highest amounts of bioavailable phosphorus were marked in the OS sample (over $74.6 \%$ of the total content) and slightly lower in the OP and OL samples (74.1 and $69.8 \%$ respectively). The least bioavailable phosphorus was obtained in OD samples. Although this method is meant to be used with bottom sediments, the ashes obtained after combustion of sediments have significantly different properties (alkaline nature, lack of organic matter) than the sediment. Due to the efficiency and simplicity of the CA method, it seems that it should be recommended for sew-

Table 3. Content of bioavailable and total phosphorus in the examined ashes $\left[\mathrm{g} \mathrm{P}_{2} \mathrm{O}_{5} / \mathrm{kg}\right.$ d.m.] and [\%] of the total phosphorus content $(\mathrm{n}=3)$

\begin{tabular}{|c|c|c|c|c|c|c|c|c|}
\hline \multirow[b]{2}{*}{ Description } & \multicolumn{2}{|c|}{$\mathrm{OP}$} & \multicolumn{2}{|c|}{$\mathrm{OL}$} & \multicolumn{2}{|c|}{ OS } & \multicolumn{2}{|c|}{ OD } \\
\hline & $\begin{array}{c}{\left[\mathrm{g} \mathrm{P}_{2} \mathrm{O}_{5} / \mathrm{kg}\right.} \\
\text { d.w.] }\end{array}$ & [\%] & $\begin{array}{c}{\left[\mathrm{g} \mathrm{P}_{2} \mathrm{O}_{5} / \mathrm{kg}\right.} \\
\text { d.w.] }\end{array}$ & [\%] & $\begin{array}{c}{\left[\mathrm{g} \mathrm{P}_{2} \mathrm{O}_{5} / \mathrm{kg}\right.} \\
\text { d.w. }]\end{array}$ & [\%] & $\begin{array}{c}{\left[\mathrm{g} \mathrm{P}_{2} \mathrm{O}_{5} / \mathrm{kg}\right.} \\
\text { d.w.] }\end{array}$ & [\%] \\
\hline WE & 0.006 & 0.004 & 0.011 & 0.008 & 0.002 & 0.001 & 0.002 & 0.043 \\
\hline $\mathrm{CA}$ & 9.840 & 5.906 & 6.225 & 4.501 & 11.865 & 6.441 & 0.296 & 6.407 \\
\hline TS & 1.998 & 1.199 & 3.516 & 2.542 & 3.749 & 2.035 & 0.283 & 6.126 \\
\hline E-R & 3.717 & 2.231 & 4.535 & 3.279 & 4.424 & 2.402 & 0.578 & 12.51 \\
\hline OLS & 1.477 & 0.887 & 0.820 & 0.593 & 0.558 & 0.303 & 0.252 & 5.45 \\
\hline G I & 5.126 & 3.077 & 4.072 & 2.944 & 8.636 & 4.688 & 0.184 & 3.983 \\
\hline G II & 38.05 & 22.84 & 28.85 & 20.86 & 32.07 & 17.41 & 0.176 & 3.810 \\
\hline G III & 78.23 & 46.96 & 62.52 & 45.20 & 94.24 & 51.16 & 1.78 & 38.53 \\
\hline G IV & 1.98 & 1.188 & 1.167 & 0.844 & 2.519 & 1.368 & 0.832 & 18.01 \\
\hline$G \Sigma$ & 123.4 & 74.06 & 96.60 & 69.85 & 137.5 & 74.63 & 2.972 & 64.33 \\
\hline P-TOT & 166.6 & 100 & 138.3 & 100 & 184.2 & 100 & 4.621 & 100 \\
\hline
\end{tabular}


age sludge ashes, with possible correction after adding the extractant to the sample. It is true that while using the Golterman method, much higher contents were obtained, but due to the timeconsuming nature and considerable workload, its use may be limited in favor of the CA method. The use of the Olsen method is justified when assessing fertilizing properties, and thus allow for a better estimation of the amount of bioavailable phosphate introduced into the soil, in case the materials are used for soil deacidification.

The ashes from municipal sewage sludge and bottom sediments are an interesting, easily available and rich source of phosphorus. The total content in the tested samples was $4.621 \mathrm{~g} \mathrm{P}_{2} \mathrm{O}_{5} / \mathrm{kg}$ d.m. in the bottom sediment and between 138.3 and $184.2 \mathrm{~g} \mathrm{P}_{2} \mathrm{O}_{5} / \mathrm{kg}$ d.m. in the sewage sludge (Table 3). However, it should be noted that as far as the use as a fertilizer is concerned, the crucial thing is the amount of bioavailable phosphorus, i.e. the part of phosphorous compounds present in a soluble form in soil, thus becoming a potential source of phosphorus for plants, while an indicated amount of total phosphorus content is here for the information purposes.

\section{CONCLUSIONS}

The recovery of phosphorus from the ashes obtained from the thermal processing of municipal sewage sludge and bottom sediments seems to be very effective, which confirms their usefulness as a source of phosphorus in agricultural production. The determination of assimilable phosphorus content was largely dependent on the method used. In the case of the tested ash samples, the Golterman method proved to be the most effective, although due to the required workload, citric acid (CA) extraction seems to be the preferred method. The distilled water extraction method gave unsatisfactory results in all cases, which confirms its unsuitability in determining phosphorus content in highly alkaline materials.

\section{REFERENCES}

1. Adam C., Peplinski B., Michaelis M., Kley G., Simon F.-G. 2009. Thermochemical treatment of sewage sludge ashes for phosphorus recovery. Waste Management 29: 1122-1128.

2. Arnout S., Nagels E. Modelling thermal phosphorus recovery from sewage sludge Ash 2016. CALPH-
AD: ComputerCouplingofPhaseDiagramsandThermochemistry55, 26-31 http://dx.doi.org/10.1016/j. calphad. 2016.06.008

3. Atienza-Martınez M., Gea G., Arauzo J., Kersten S.R.A., Maarten A., Kootstra J.2014. Phosphorus recovery from sewage sludge char Ash. Biomass and bioenergy 65, 42-50. doi.org/10.1016/j.biombioe. 2014.03 .058

4. Bednarek W., ReszkaR. 2007. The effect of liming and fertilization with various nitrogen forms on the content

5. of available forms and mineral fractions of phosphorus in the soil. Annales Universitatis Mariae Curie - Skłodowska Lublin - Polonia Vol. Lxii (2) Sectio E 234-242 (in Polish)

6. Bezak-Mazur E., Stoińska R. 2013. Speciation of phosphorus in wastewater sediments from selected wastewater treatment plant. Ecol Chem Eng A. 20(4-5): 503-514. DOI: 10.2428/ ecea.2013.20(04)047

7. Bień J.D. 2012. Utilisation of Sewage Sludge in Poland by Thermal Method. Inżynieria i Ochrona Środowiska 15(4): 439-449 (in Polish)

8. Bøen A., Haraldsen T.K., Krogstad T. 2013. Large differences in soil phosphorus solubility after the application of compost and biosolids at high rates. Acta Agriculturae Scandinavica, Section B - Soil \& Plant Science. DOI: 10.1080/09064710.2013.801508

9. Chiu S.W., Gao T., Chan,C.S.S., Ho C.K.R. 2009. Removal of spilled petroleum in industrial soils by spent compost of mushroom Pleurotus pulmonarius. Chemosphere 75 837-842

10. Ciesielczuk T., Rosik-Dulewska Cz., Kusza G. 2016. Extraction of phosphorus from sewage sludge ash and sewage sludge - problem analysis. Polish Journal for Sustainable Development 20, 21-28, DOI: 10.15584/pjsd.2016.20.3 (in Polish)

11. Czechowska-Kosacka A. 2016. Phosphorus Speciation Forms in Sewage Sludge from Selected Wastewater Treatment Plants. Annual Set The Environment Protection 18: 158-168

12. Ebbers B., Ottosen L.M., Jensen P.E. 2015. Comparison of two different electrodialytic cells for separation of phosphorus and heavy metals from sewage sludge ash. Chemosphere 125: 122-129.

13. Golterman H.L. Hydrobiologia. 1996. 335(1);87-95. DOI: $10.1007 / \mathrm{BF} 00013687$

14. Guedes P., Couto N., Ottosen L.M., Ribeiro A.B. 2014. Phosphorus recovery from sewage sludge ash through an electrodialytic process. Waste Management 34: 886-892.

15. Guedes P., Couto N., Ottosen L.M., Kirkelund G.M., Mateus E., Ribeiro A.B. 2016. Valorisation of ferric sewage sludge ashes: Potential as a phosphorus source. Waste Management 52: 193-201. 
16. Havukainen J., Nguyen M.T., Hermann L., Horttanainen M., Mikkilä M. Deviatkin I., Linnanen L. 2016. Potential of phosphorus recovery from sewage sludge and manure ash by thermochemical treatment. Waste Management 49, 221-229.

17. Herzel H., Krüger O., Hermann L., Adam Ch. 2016. Sewage sludge ash - A promising secondary phosphorus source for fertilizer production. Science of the Total Environment 542, 1136-1143.

18. Hukari S., Hermann L., Nättorp A. 2016. From wastewater to fertilisers - Technical overview and critical review. Science of the Total Environment 542, 1127-1135.

19. Kruger O., Adam Ch. 2015. Recovery potential of German sewage sludge Ash. Waste Management 45, 400-406.

20. Krupa-Żuczek K., Podraza Z., Wzorek Z. 2012 Extraction of phosphorus from sewage sludge ash and sewage sludge - problem analysis. Chemistry. Technical Transactions 16, 65-70 (in Polish)

21. Mazur Z., Radziemska M., Tomaszewska Z., Świątkowski Ł. 2013. Effect of sodium chloride salinization on the seed germination of selected vegetable plants. Scientific Review - Engineering and Environmental Sciences 62, 444-453.

22. Olsen SR, Cole CV, Watanabe FS, Dean LA (1954) Estimation of available phosphorus in soils by extraction with sodium bicarbonate. USDA Circular $\mathrm{Nr}$ 939, US Gov Print Office, Washington, DC, pp 1-19.

23. Petzet S., Peplinski B., Cornel P. 2012. On wet chemical phosphorus recovery from sewage sludge ash by acidic or alkaline leaching and an optimized combination of both. water research 46, 3769-3780.

24. Poluszyńska J. 2013. Assessment of contamination possibility of soil by polycyclic aromatic hydrocarbons (PAHs) contained in the fly ash from power boilers. Scientific Works of Institute of Ceramics and Building Materials 12, 60-77 (in Polish)

25. Poluszyńska J., Ślęzak E. 2015. Phosphorus from municipal sewage sludge. Scientific Works of Institute of Ceramics and Building Materials 22, 44-55 (in Polish)

26. Rosik-Dulewska Cz., Karwaczyńska U., Głowala K., Robak J. 2008. Elution of heavy metals from granulates produced from municipal sevage deposits and fly-ash of hard and brown in the aspect of recycling for fertilization purposes. Archives of Environment Protection 34( 2), 63-71.

27. Rosik-Dulewska Cz., Nocoń K., Karwaczyńska U. 2016 Wytwarzanie granulatu z komunalnych osadów ściekowych i popiołów lotnych w celu ich przyrodniczego (nawozowego) odzysku (in Polish).
Instytut Podstaw Inżynierii Środowiska Polskiej Akademii Nauk, Prace i Studia 87, pp. 187.

28. Seshadri B., Bolan N., Choppala G., Naidu R. 2013. Differential effect of coal combustion products on the bioavailability of phosphorus between inorganic and organic nutrient sources. Journal of Hazardous Materials 261 (2013) 817-825, http://dx.doi. org/10.1016/j.jhazmat.2013.04.051.

29. Shiba N.C., Ntuli F. 2016. Extraction and precipitation of phosphorus from sewage sludge. Waste Management http://dx.doi.org/10.1016/j.wasman.2016.07.031.

30. Statistical Yearbook of Environmental Protection 2017. Central Statistical Office Warszawa 2017.

31. Strzebońska M., Kostka A., Helios-Rybicka E., Jarosz-Krzemińska E. 2015. Effect of Flooding on Heavy Metals Contamination of Vistula Floodplain Sediments in Cracow; Historical Mining and Smelting as the Most Important Source of Pollution. Polish J. of Environ. Stud., 34, (3), 1317-1326, doi 10.15244/pjoes/33202

32. Szaja A. 2013. Phosphorus Recovery from Sewage Sludge via Pyrolysis. The Annual Set the Environment Protection 15, 361-370.

33. Szpak P., Millaire J.F., White Ch.D., Longstaffe F.J. 2012. Influence of seabird guano and camelid dung fertilization on the nitrogenisotopic composition of field-grown maize (Zea mays). Journal of Archaeological Science 39, 3721-3740.

34. Tujaka A., Gosek S., Gałązka R. 2006. Estimation of Hedley's fractionation method applicability to the determination of changes in phosphorus fractions in soil Polish Journal of Agronomy 2011, 6, 52-57 (in Polish)

35. van Vuuren D.P., Bouwman A.F., Beusen, A.H.W. 2010. Phosphorus demand for the 1970-2100 period: A scenario analysis of resource depletion. Global Environmental Change 20(3), 428-439. doi:10.1016/j.gloenvcha.2010.04.004

36. Weigand H., Bertau M., Hübner W., Bohndick F., Bruckert A. 2013. RecoPhos: Full-scale fertilizer production from sewage sludge Ash. Waste Management 33, 540-544.

37. Wzorek Z. 2008. The pfosphorus compounds recovery from thermally treated waste and its use as substitute of natural phosphorus raw materials. Monogrph 356 Kraków 2008. (in Polish)

38. Wzorek Z., Jodko M., Gorazda K., Rzepecki T. 2006. Extraction of phosphorus compounds from ashes from thermal processing of sewage sludge. Journal of Loss Prevention in the Process Industries $19,39-50$. 